\title{
PELAYANAN SOSIAL BAGI ANAK JALANAN DITINJAU DARI PERSPEKTIF PEKERJAAN SOSIAL
}

\author{
Oleh: \\ Melisa Amalia Amin, Hetty Krisnani, dan Maulana Irfan \\ Email: \\ aminmelisa@gmail.com; hettykrisnany@yahoo.com; sangirfan@yahoo.com
}

\begin{abstract}
Abstrak
Artikel ini membahas pelayanan sosial bagi anak jalanan yang dilakukan oleh salah satu Lembaga Sosial. Bagi lembaga sosial yang memberikan pelayanan kepada anak jalanan melalui rumah singgah, maka pelayanan yang diberikan menurut perspektif pekerjaan sosial dapat menggunakan model pelayanan Half-Way House Services. Adapun model pelaksanaan pelayanan menurut strategi ini dapat menggunakan teori proses pekerjaan sosial yang terdiri atas Engagement, Intake \& Contract, Assessment, Planning, Intervention, Evaluation \& Termination. Pada artikel ini, Salah satu lembaga sosial memberikan pelayanan kepada anak jalanan melalui pelatihan keterampilan, family development dan home visit. Dimana, sebelum menentukan bentuk pelayanan, lembaga ini sudah menggunakan proses pekerjaan sosial dan didalam pemberian pelayanan, masih dibutuhkan usaha untuk meningkatkan pelayanan bagi lembaga ini. Upaya untuk meningkatkan pelayanan ditinjau dari perspektif pekerjaan sosial dapat menggunakan sistem dasar yang terdiri atas sistem pelaksana perubahan, sistem klien, sistem sasaran dan sistem kegiatan.

Kata Kunci : Anak Jalanan, Pelayanan, Pekerjaan Sosial

Pendahuluan

Anak Jalanan merupakan fenomena yang sudah tidak asing lagi di Indonesia. Semakin menjamurnya jumlah anak jalanan yang berkeliaran di jalan mengakibatkan permasalahan yang cukup besar di Indonesia, terutama pada kota-kota besar seperti Jakarta, Bandung, dan Surabaya. Kota Bandung sebagai kota metropolitan juga tidak terlepas dari masalah anak jalanan. Walaupun untuk tahun 2014 jumlah anak jalanan sulit untuk diperkirakan, akan tetapi data terakhir yang diperoleh dari BPS Kota Bandung (2012) dalam Rancangan Pembangunan Jangka Menengah Daerah Kota Bandung 2014-2018 mengenai masalah kesejahteraan sosial di Bandung pada tahun 2011 menunjukan bahwa jumlah anak jalanan masih banyak dan dapat dilihat pada tabel 1.1 dibawah ini.
\end{abstract}




\section{Tabel 1.1 Masalah Kesejahteraan Sosial di Kota Bandung Pada Tahun 2011}

$\begin{array}{llll}\text { No } & \text { Jenis Masalah } & \text { Satuan } & \text { Jumlah } \\ 1 & \text { Gelandangan } & \text { Orang } & 948 \\ 2 & \text { Pengemis } & \text { Orang } & 4.162 \\ 3 & \text { Wanita Tuna Susila } & \text { Orang } & 549 \\ 4 & \text { Bekas Narapidana } & \text { Orang } & 364 \\ 5 & \text { Anak Jalanan } & \text { Orang } & 4861\end{array}$

Sumber Data: BPS Kota Bandung Dalam Angka, 2012

Keberadaan anak dijalanan, merupakan sesuatu yang sangat dilematis. Selain mencari nafkah untuk mendapakan uang yang membuatnya bertahan hidup, keberadaan anak dijalanan sering menganggu ketertiban umum dan hak mereka sebagai anak untuk mendapatkan kasih sayang, pendidikan dan penghidupan yang layak tidak terpenuhi sehingga dapat merusak kehidupan mereka dimasa depan. Mereka merupakan kelompok sosial yang sangat rentan dari berbagai tindakan fisik, emosi,seksual ataupun kekerasan sosial lainnya.

Berbagai upaya untuk menangani keberadaan anak jalanan telah dilakukan pemerintah. Salah satunya dengan mengeluarkan kebijakan terkait perlindungan dan hak anak. Berdasarkan Intruksi Presiden No 3 tahun 2010 tentang pembangunan program yang berkeadilan, ditetapkan sebuah Program Kesejahteraan Sosial Anak (PKSA) sebagai program prioritas nasional, yang didalamnya termasuk Program Kesejahteraan Sosial Anak Jalanan (PKS-Anjal) dengan Lembaga Kesejahteraan Sosial Anak (LKSA) sebagai wadah yang melaksanakan Program Kesejahteraan Sosial Anak Jalanan.

Dalam menangani keberadaan anak jalanan, salah satu Lembaga Kesejahteraan Sosial Anak dalam hal ini Lembaga Swadaya Masyarakat (LSM), menganggap perlu adanya suatu pelayanan bagi anak jalanan. Banyak LSM yang melakukan pelayanan terhadap anak jalanan tetapi hasilnya kurang maksimal. Hal ini dijelaskan oleh Departemen Sosial (2005):

Program pembinaan anak jalanan di LSM-LSM dapat dikatakan belum maksimal karena masih belum banyak inovasi baru yang dilakukan dan banyak juga program pembinaan yang dilakukan tidak berkelanjutan yang berdampak banyak anak jalanan kembali kepekerjaan awal mereka di jalanan dan semakin kompleks permasalahan yang mereka hadapi. (Departemen Sosial. 2005. Petunjuk Teknis Pelayanan Sosial Anak Jalanan)

Selain program pembinaan, permasalahan lainnya didalam pelayanan sosial yang diberikan terletak pada pelayanan yang diberikan masih sebatas kepada anak jalanan dan belum menyentuh keluarga anak. Tidak hanya itu, permasalahan umum yang terjadi pada pelayanan sosial adalah minimnya sumber daya manusia dan minimnya sumber pendanaan.

Dengan penjelasan tersebut maka dibutuhkan penyelesaian yang tepat untuk diberikan kepada anak jalanan. Karena upaya untuk mewujudkan perlindungan dan kesejahteraan anak dengan memenuhi hak-haknya telah dirumuskan di dalam UU No. 4 Tahun 1979 tentang kesejahteraan anak dan UU No. 23 Tahun 2002 tentang perlindungan anak jalanan. Realisasi dari peraturan negara ini salah satunya bisa terwujud dengan dilaksanakannya rumah singgah, rumah perlindungan anak atau rumah perlindungan sosial anak, mobil sahabat anak, panti persinggahan dan program-program lainnya untuk anak jalanan yang mana pasal didalamnya menjelaskan bahwa usaha kesejahteraan anak terdiri atas usaha pembinaan, pengembangan, pencegahan dan rehabilitasi yang dilakukan oleh pemerintah dan atau masyarakat sebagai dasar dari hak anak untuk tumbuh dan berkembang.

Di Bandung, Sebagai salah satu contoh, Yayasan Saudara Sejiwa merupakan salah satu rumah singgah dan dikenal dengan nama Rumah Perlindungan Anak (RPA) yang turut mendukung dan 
membantu pemerintah dalam membina anak jalanan agar anak tidak kembali kejalanan. Pelayanan yang diberikan oleh Rumah Perlindungan Anak yang dikelola Yayasan Saudara Sejiwa pada umumnya sama dengan pelayanan yang diberikan yayasan lainnya.

Hanya saja, perbedaan pelayanan sosial yang diberikan terletak pada tahap pelayanan yang diberikan. Dan tahapan ini menentukan jenis kegiatan yang dilaksanakan. Berdasarkan hasil observasi awal kepada Rumah Perlindungan Anak (RPA) yang dikelola yayasan, diketahui bahwa layanan yang diberikan bagi anak jalanan saat ini berupa penjangkauan, Assessment, rencana pelayanan, persiapan kegiatan, dan kegiatan yang sedang berjalan berupa pelatihan keterampilan yang terdiri atas pelatihan menjahit serta komputer, pembinaan sikap dan mental positif, home visit (kunjungan kerumah atau keluarga anak jalanan) serta family Develpoment System yang diberikan kepada orang tua dari anak jalanan yang menjadi anak binaan, diakhiri dengan terminasi.

Yayasan ini membina anak didalam rumah singgah yang dikenal dengan nama rumah perlindungan anak (RPA) dimana anak hanya sekedar singgah dan tidak menetap. Strategi pelayanan sosial yang diterapkan oleh Yayasan Saudara Sejiwa merujuk pada Half-way House Services yang dapat berbetuk rumah persinggahan anak dan keluarganya, sebagaimana yang dijelaskan oleh Suharto (1997):

Dimana Strategi ini disebut juga strategi semi-panti yang lebih terbuka dan tidak kaku. Strategi ini dapat berbentuk rumah singgah, rumah terbuka untuk berbagai aktivitas, rumah belajar, rumah persinggahan anak dengan keluargannya, rumah keluarga pengganti, atau tempat anak yang mengembangkan sub-kultur tertentu. Para pekerja sosial menentukan program kegiatan. (Suharto, 1997:373)

Adapun pelaksanaan model pelayanan Half-way House Services menurut Soetarso (1996) dapat mengikuti struktur dan mekanisme praktek pekerjaan sosial yang terdiri dari "Identifikasi masalah, penyelidikan, Intervensi sosial dan terminasi." Struktur dan mekanisme praktek pekerjaan sosial didalam pelayanan sosial dikenal juga dengan nama proses pertolongan atau proses pekerjaan sosial.

Ditinjau dari perspektif pekerjaan sosial, proses pertolongan atau proses pekerjaan sosial merupakan wujud praktik pekerjaan sosial. Sebagai sebuah wujud praktik dari pekerjaan sosial, maka pelayanan sosial yang diberikan akan selalu berkaitan dengan proses pekerjaan sosial. Serupa halnya dengan pelayanan sosial yang diberikan saudara sejiwa jika ditinjau dari perspektif pekerjaan sosial, maka akan selalu berkaitan dengan proses pekerjaan sosial.

Proses pekerjaan sosial mempunyai tahapan pertolongan yang berbeda-beda. Adapun salah satu ahli, Max Siporin (1997) dalam Wibhawa (2010) menjelaskan bahwa proses pekerjaan sosial terdiri atas :

"Engagement, Intake \& Contract, Assessment, Planning, Intervention, Evaluation \&

Termination. Setiap tahapan (proses) mesti dilalui dalam mengatasi suatu persoalan sosial tertentu. (Wibhawa,dkk.2010:63)

Berdasarkan uraian diatas, diketahui dalam mendeskripsikan pelayanan sosial yang diberikan oleh Half-way House Services seperti RPA yang dikelola Yayasan Saudara Sejiwa, dapat ditinjau dari aspek-aspek yang terdapat pada tahapan pelayanan yang dilakukan. Yang mana, ditinjau dari perspektif pekerjaan sosial tahap-tahap pelayanan ini dikenal dengan nama proses pekerjaan sosial.

\section{Metode, hasil dan pembahasan}

Dalam meninjau pelayanan sosial bagi anak jalanan, terlebih dahulu harus diketahui mengenai definisi anak jalanan menurut para ahli. Anak jalanan dapat dideskripsikan sebagai anak yang menggunakan sebagian besar waktunya dijalan baik untuk bekerja atau tidak bekerja yang mana keberadaan mereka dijalanan dapat menganggu ketentraman orang lain serta membahayakan diri mereka. Pengertian ini merupakan kesimpulan dari definisi anak jalanan menurut beberapa ahli. Lusk (1989:57-58) dalam hayat (2010:14) menjelaskan yang dimaksud dengan anak jalanan adalah 
"Setiap anak perempuan atau laki-laki yang memanfaatkan jalanan menjadi tempat tinggal sementara atau sumber kehidupan dan tidak dilindungi, diawasi atau diatur oleh orang dewasa yang bertanggung jawab."

Sedangkan menurut A Soedijar Z.A dalam Sanusi (1997:24) mengemukakan definisi anak jalanan sebagai berikut:

"Anak jalanan adalah anak yang berusia 7-15 tahun yang bekerja dijalan raya dan ditempat umum lainnya yang dapat menganggu ketentraman dan keselamatan orang lain serta membahayakan keselamatan dirinya sendiri."

Dari dua definisi anak jalanan diatas, diketahui bahwa anak jalanan merupakan anak dengan rentang usia dibawah 18 tahun yang menggunakan sebagian besar waktunya dijalan baik untuk bekerja maupun tidak, dimana keberadaan mereka dapat membahayakan keselamatan orang lain dan dirinya sendiri.

Berdasarkan intensitasnya di jalanan, anak jalanan dapat dikelompokan menjadi tiga kategori utama menurut Depdiknas(2000) yaitu :

1. Children of the street

Anak yang hidup dan tinggal di jalanan dan tidak ada hubungan dengan keluarganya. Kelompok ini biasanya tinggal di terminal, stasiun kereta api, emperan toko dan kolong jembatan.

2. Children on the street

Anak yang bekerja di jalanan. Umumnya mereka adalah anak putus sekolah, masih ada hubungannya dengan keluarga namun tidak teratur yakni mereka pulang ke rumahnya secara periodik

3. Vulberable children to be street children

Anak yang rentan menjadi anak jalanan. Umumnya mereka masih sekolah dan putus sekolah, dan masih ada hubungan teratur (tinggal) dengan orang tuanya.

Anak turun ke jalanan disebabkan oleh berbagai sebab. Ada beberapa faktor yang menyebabkan anak turun ke jalan, faktor tersebut menurut Huraerah (2003) adalah:

A. Kemiskinan

Kemiskinan selalu diasosiasikan dengan munculnya berbagai gejala sosial. Keluarga yang miskin akan mengerahkan semua sumber daya manusianya untuk menambah penghasilan keluarga. Oleh karena itu, selain orang tua yang bekerja, anak-anak sudah dituntut bekerja.

B. Partisipasi Sekolah

Faktor makro lainnya yang sering dihubungkan dengan anak-anak yang menghabiskan waktu luangnya di jalanan adalah partisipasi sekolah. Kita dapat berasumsi bahwa jika anak-anak itu bersekolah, maka sebagian waktunya tidak akan berada di jalanan.

C. Disfungsi Keluarga

Penelitian yang khusus mengacu pada anak-anak yang dikategorikan sebagai of the street oleh UNICEF, menunjukan bahwa motivasi mereka di jalanan bukanlah sekedar ekonomi. Kekerasan keluarga dan keretakan keluarga merupakan tema sentral dalam wawancara dengan mereka. Bagi anak-anak ini, kehidupan di jalanan yang keras lebih memberikan alternatif kekerasan jika dibandingkan dengan hidup dalam keluarganya yang penuh kekerasan.(Huraerah,2003:121-139)

Dari penjelasan di atas, diketahui ada berbagai macam penyebab yang mengakibatkan anak berada dijalanan. Untuk itu, model penanganan terhadap anak selalu berbeda dan disesuaikan dengan kondisinya. Pada saat ini, alternatif penanganan anak jalanan mengarah ke pemberian pelayanan 
sosial kepada anak jalanan yang dilakukan oleh Rumah Perlindungan Anak (RPA). Pada hakikatnya, RPA sama dengan Rumah Singgah. Hanya saja, beberapa lembaga menggunakan nama yang berbeda untuk penyebutannya. Akan tetapi, pada saat sekarang ini, Rumah Singgah dikenal dengan nama RPA.

RPA sebagai sebuah bentuk pelayanan kesejahteraan sosial kepada anak, maka pelayanan ini berhubungan dengan Pekerjaan Sosial. Adapun definisi mengenai pekerjaan sosial menurut Scrafia (1983) dalam Wibhawa, dkk (2010:45) memaparkan pengertian pekerjaan sosial sebagai :

Social work is the profesion which is primaly concerned with organized social service activity aimed to facilitate and strengthen basic relationship in the mutual adjustment between individual, and their social environtment for the good of the individual and society, by the use of social work method.

Pekerjaan sosial adalah profesi yang bidang utamannya berkecimpung dalam kegiatan pelayanan sosial yang terorganisasi, dimana tujuannya untuk memfasilitasi dan memperkuat relasi dalam penyesuaian diri secara timbal balik dan saling menguntungkan antar individu dengan lingkungan sosialnya, melalui penggunaan metode-metode Pekerjaan Sosial. (Scrafica, 1983:3)

Hampir serupa dengan Scrafica, Friedlander, walter dan Apte (1980) dalam Wibhawa, $\operatorname{dkk}(2010: 45)$ menjelaskan mengenai pekerjaan sosial yaitu :

"Social work is a professional service, based on scientific knowledge and skill in human relation. Which help individuals, groups, or communities obtain social or personal satisfication and interdepedence."

Pekerjaan sosial adalah pelayanan profesional yang didasarkan pada pengetahuan dan keterampilan ilmiah guna membantu individu, kelompok maupun masyarakat agar tercapainya kepuasan pribadi dan sosial serta kebebasan. (Friedlander, Walter A. Dan Apte 1980:4)

Dari dua definisi diatas, dijelaskan bahwa pekerjaan sosial adalah pelayanan profesional yang didasarkan pengetahuan dan keterampilan guna membantu individu dalam hal ini anak jalanan. Pengetahuan dan keterampilan dari pekerjaan sosial salah satunya meliputi proses pekerjaan sosial guna membantu individu, kelompok maupun masyarakat. Jika dikaitkan dengan pelayanan sosial yang diberikan kepada anak jalanan, maka diketahui, RPA merupakan sebuah wadah pelayanan sosial yang terorganisasi untuk membantu anak jalanan. Dengan demikian, sebagai sebuah wadah yang membantu anak jalanan, maka bisa dikatakan, bahwa pekerjaan sosial sedang dilakukan didalam RPA melalui tahapan pelayanan sosial yang diberikan kepada anak jalanan.

Pekerjaan sosial sangat berperan penting didalam pelayanan kepada anak. Pelayanan sosial yang diberikan kepada anak jalanan, dikenal dengan nama pelayanan kesejahteraan sosial bagi anak. Adapun strategi yang menjurus kepada pelayanan kesejahteraan sosial bagi anak menurut Suharto terbagi atas beberapa strategi :

1. Child Based Services.

2. Institutional Based Services.

3. Family Based Service

4. Community Based Services.

5. Location Based Services.

6. Half-way House Services.

7. State Based Service. (Suharto, 1997:373-375)

Soetarso (1996) dalam Suharto (1997) selanjutnya menjelaskan, Adapun pelaksanaan model pelayanan Half-way House Services menurut Soetarso (1996) dapat mengikuti struktur dan mekanisme praktek pekerjaan sosial yang terdiri dari "Identifikasi masalah, penyelidikan, Intervensi 
sosial dan terminasi." Struktur dan mekanisme praktek pekerjaan sosial didalam pelayanan sosial dikenal juga dengan nama proses pertolongan atau proses pekerjaan sosial.

Rumah Perlindungan Anak sebagai wadah penanganan anak jalanan, dalam memberikan pelayanan kepada anak binaan menggunakan strategi pelayanan Half-way House Services dimana anak-anak jalanan dan keluarga anak bisa datang kapanpun ke rumah perlindungan anak dan Pekerja Sosial yang berada di rumah ini, menentukan program kegiatan serta berbagai rumah perlindungan anak ini bersama dengan pengurus RPA. Dalam membahas pelayanan sosial yang diberikan oleh RPA, peneliti meninjau aspek-aspek yang terdapat pada tahapan pelayanan sosial yang dilakukan oleh RPA pada umumnya yang meliputi penjangkauan, assessment, rencana pelayanan, persiapan kegiatan, kegiatan dan tahap terakhir adalah terminasi.

1. Penjangkauan

Merupakan Tahap pertama yang mesti dilalui didalam pelayanan sosial yang diberikan kepada anak binaan oleh Yayasan. Adapun penjangkauan ditinjau dari perspkektif pekerjaan sosial menurut Max Siporin (1975:193) merujuk kepada engagment,intake dan contract. Adapun Engagment merupakan suatu periode dimana pekerja sosial mulai berorientasi terhadap dirinya sendiri, khususnya mengenai tugas-tugas yang ditanganinya. Dalam hal ini, pekerja sosial yang bekerja dengan anak jalanan mulai berorientasi terhadap dirinya dan tugas-tugas mengenai anak jalanan yang ditanganinya. Lalu, proses ini diikuti dengan kontak awal pekerja sosial dengan penerima pelayanan dalam hal ini anak jalanan dan pihak-pihak terkait yang selanjutnya diikuti dengan kontrak antara pekerja sosial dan penerima pelayanan.

2. Assessment

Merupakan tahap kedua yang mesti dilalui oleh anak binaan di Rumah perlindungan anak. Ditinjau dari perspektif pekerjaan sosial, Dalam kegiatan Assesment ini, pekerja sosial melakukan identifikasi masalah dan kebutuhan, menentukan sumber-sumber yang dibutuhkan dalam upaya pemecahan masalah, mengumpulkan dan menganalisa data serta merumuskan masalah yang dihadapi penerima pelayanan.

3. Rencana Pelayanan

Ditinjau dari proses pekerjaan sosial, tahap ini merupakan tahap planning. Max Siporin(1975:251) memberikan pengertian planning sebagai berikut :

"Planning defined as a deliberate, rational process that involves the choice of actions that are calcurated to achieve specifik objectives at some future time." It also is describe as policy choice and programming in the light of facts. Projection and application of value." (Perencanaan didefinisikan sebagai sebuah perundingan, proses rasional yang melibatkan pilihan, tindakan-tindakan yang diperhitungkan untuk mencapai tujuan-tujuan spesifik di waktu yang akan datang dan program yang dilihat dari fakta-fakta, proyeksi dan aplikasi nilai-nilai)

4. Persiapan Kegiatan dan Pelaksanaan Kegiatan

Ditinjau dari proses pekerjaan sosial, tahap ini merupakan tahap intervensi Pada tahap ini dilaksanakan kegiatan-kegiatan pemecahan permasalahan penerima pelayanan selain itu, dalam pelaksanaan intervensi ini, pekerja sosial dituntut untuk berusaha melibatkan penerima pelayanan secara aktif pada setiap kegiatan yang dilakukannya. Adapun kegiatan yang diberikan kepada anak berupa pendidikan dan pelatihan vocational (kecakapan hidup) seperti pelatihan keterampilan yang terdiri atas pelatihan menjahit serta komputer, pembinaan sikap dan mental positif, home visit (kunjungan kerumah atau keluarga anak jalanan) serta family Develpoment System yang diberikan kepada orang tua dari anak jalanan yang menjadi anak binaan, lalu selanjutnya ditinjau dari perspketif Pekerjaan Sosial dilanjutkan dengan tahap evaluasi. Pada tahap ini, pekerja sosial melakukan penilaian kembali semua kegiatan pertolongan yang telah dilaksanakan untuk melihat tingkat 
keberhasilan maupun hambatan-hambatannya. Dalam tahap ini pekerja sosial memulai kembali apa yang telah dilakukan. Evaluasi merupakan unsur yang cukup penting dalam pertolongan, Karena memungkinkan suatu lembaga memberikan respon dan pertanggung jawaban, baik kepada klien maupun kepada keluarga klien. Kegiatan ini dilakukan untuk melihat kembali semua kegiatan yang telah dilakukan untuk melihat tingkat keberhasilan, kegagalan dan juga kendala.

5. Terminasi

Tahap pelayanan terakhir yang diberikan oleh RPA sama dengan tahap terakhir pada proses pekerjaan sosial yakni tahap terminasi. Ditinjau dari proses pekerjaan sosial, terminasi merupakan tahap pengakhiran kegiatan pertolongan pekerjaan sosial yang dilakukan apabila tujuan pertolongan telah tercapai atau penerima pelayanan memerlukan rujukan kelembaga lain. Sedangkan terminasi yaitu tahap paling akhir dalam proses pelayanan sosial. Tahap terminasi dilakukan bila tujuan pertama telah dicapai. Terminasi adalah perencanaan awal kerjasama antara pekerja sosial dengan klien, terminasi dapat meningkatkan fungsi sosial klien dan juga dapat mengembangkan pengertian antara klien dan pekerja sosial saat mereka bekerja sama. Tidak hanya pekerja sosial yang melakukan tahapan ini. Akan tetapi, para pengurus yayasan yang bekerja dengan anak juga sebaiknya melakukan tahap-tahap proses pekerjaan sosial didalam memberikan pelayanan sosialnya bagi anak jalanan.

Walaupun lembaga sosial ini telah menggunakan proses pekerjaan sosial dalam menentukan bentuk pelayanan, akan tetapi pelayanan yang diberikan masih perlu ditingkatkan.

\section{Penutup (Simpulan dan Saran)}

Sebagai seorang pekerja sosial yang bekerja dengan anak, Maka saran yang bisa diberikan berupa peningkatan pelayanan dengan memperhatikan sistem lingkungan yang disebut dengan sistem dasar. Dalam perpektif pekerjaan sosial, sistem lingkungan memiliki kontribusi signifikan dalam proses dan praktek pekerjaan sosial, Sistem dasar ini merupakan significant factors yang harus diidentifikasi dan diklasifikasikan oleh pekerja sosial dalam menjalankan peran-peran profesionalnya. Pincus dan Minahan (1973) dalam Suharto (1997:319) sistem dasar ke dalam empat jenis, yaitu :

1. Sistem Pelaksana perubahan (change agent system).

Sistem pelaksana perubahan adalah sekelompok orang yang tugasnya memberi bantuan atas dasar keajian yang berbeda-beda dan bekerja dengan sistem yang berbeda-beda pula ukurannya. Seorang pekerja sosial dapat disebut sebagai pelaksana perubahan, sementara itu lembaga-lembaga kesejahteraan sosial yang mempekerjakannya disebut sebagai sistem pelaksana perubahan.

Dalam meningkatkan pelayanan, Lembaga sosial merupakan sistem pelaksana perubahan, Dan orang-orang yang berada pada lembaga sosial merupakan pelaksana perubahan. Jika lembaga sosial sudah mempunyai sistem yang jelas ukurannya dalam memberikan pelayanan, maka pelayanan dapat meningkat. Sebagai contoh, jika lembaga memberikan pelatihan maka pelatihan itu harus dibuat ukuran yang jelas seperti rentang waktu pelatihan, metode pelatihan,dan evaluasi dari pelatihan.

2. Sistem klien

Sistem klien dapat merupakan individu, kelompok, keluarga, organisasi atau masyarakat yang meminta bantuan atau pelayanan kepada sistem pelaksana perubahan. Pada artikel ini, yang merupakan klien adalah anak jalanan beserta keluargannya. Lembaga sosial sebaiknya sudah mengetahui siapa saja klien yang akan diberi bantuan, sehingga dalam memberikan pelayanan, bentuk pelayanan tidak hanya ditujukan kepada anak tetapi juga kepada keluargannya dan dengan adanya pengetahuan mengenai sistem klien, maka pelayanan 
yang diberikan oleh lembaga akan banyak ragam serta jenisnnya disesuaikan dengan siapa kliennya.

3. Sistem Sasaran

Sistem sasaran adalah pihak-pihak yang dapat dijadikan sasaran perubahan, atau dijadikan media yang dapat mempengaruhi proses pencapaian tujuan pertolongan. Jika pelayanan yang diberikan oleh lembaga sosial belum ada baik dalam segi sumber daya yang kurang atau dana yang belum memadai, dengan menggunakan pengetahuan mengenai sistem sasaran, maka lembaga akan mencari pihak-pihak yang dapat diajak bekerjasama untuk memaksimalkan pelayanan. Misalnnya, PKBM setempat sebagai rujukan, jika klien tidak bisa baca dan tulis.

4. Sistem Kegiatan

Sistem kegiatan menunjuk pada orang-orang yang bekerja sama dengan pekerja sosial untuk melakukan usaha-usaha perubahan melalui pelaksanaan tugas-tugas atau program kegiatan.(Pincus, 1973:53-68)

Pelayanan dapat ditingkatkan dengan menggunakan pengetahuan dari sistem kegiatan. Carannya, dari setiap pelayanan yang diberikan, Lembaga sebaiknya sudah menunjuk orang-orang yang bertanggung jawab, selain pekerja sosial dan juga orang-orang yang bisa diajak bekerja sama dalam setiap pelayanan yang diberikan.

Adanya 4 sistem ini, diharapkan dapat digunakan oleh pengurus yayasan beserta pekerja sosial agar tecipta pelayanan kesejahteraan sosial bagi anak yang lebih baik.

\section{Daftar Pustaka}

Departemen Sosial RI.2005. Petunjuk Teknis Pelayanan Sosial Anak Jalanan. Departemen Sosial Republik Indonesia. Jakarta

Direktorat Kesejahteraan Anak \& Direktorat Jendral Rehabilitasi Sosial Ri. 2010. Pedoman Pendampingan Kesejahteraan Anak (PKSA).Kementrian Sosial Republik Indonesia. Jakarta

Friedlander dan Apte.Z. 1980. Introduction to Social Welfare. United State : University Of California At Berkeley

Hayat, Abdul. Kekerasan terhadap anak jalanan .2010. Yogyakarta: B2P3KS Press.

Huraerah, Abu. 2003. Isu Kesejahteraan Sosial.Bandung: Centre for political and local Autonomy Studies.

Iskandar, Yusman .1993. Strategi Dasar Membangun Kekuatan Masyarakat. Bandung: Koperasi Mahasiswa Sekolah Tinggi Kesejahteraan Sosial

Siporin, Max. 1975. Introduction To Social work Practice. United State Of America : Macmillan Publishing co.inc

Suharto,Edi.2005. Membangun Masyarakat Memberdayakan Rakyat. Bandung : Refika Utama

Suharto,Edi.1997.Pembangunan Kebijakan Sosial dan Pekerjaan sosial; spektrum pemikiran: Lembaga studi pembangunan LSP-STKS Bandung.

Sukoco, Dwi Heru. 1991. Profesi pekerjaan sosial dan proses pertolongannya. Bandung : Kopma STKS

Soetarso.1997. Kesejahteraan sosial, pelayanan sosial dan kebijakan sosial. Jakarta : Bina Aksara

Wibhawa, Budi dkk. 2010. Dasar- Dasar Pekerjaan sosial. Bandung: Widya padjadjaran

\section{Sumber lain}

Krismiyarsi,Dkk. 2004. Efektivitas Kebijakan Pemerintah Mengenai Penanganan Anak Jalanan Melalui Model Rumah Singgah. Laporan Penelitian. Fakultas Hukum Universitas 17 Agustus 1945. Semarang.

http://sdc.depsos.go.id/diakses 6 september 2014, pada pukul 09.02 WIB 
http://bandung.go.id/site/RPJMD_2014/Rancangan_Akhir_RPJMD_2014_02_16.pdf， di unduh 8 september 2014 